\title{
Future Perspectives on Pathogenesis of Lupus Nephritis
}

\section{Facts, Problems, and Potential Causal Therapy Modalities}

\author{
Ole P. Rekvig, ${ }^{* \dagger \ddagger}$ Dhivya Thiyagarajan, ${ }^{*}$ Hege L. Pedersen, ${ }^{*}$ Kjersti D. Horvei, ${ }^{*}$ and Natalya Seredkina*
}

From the RNA and Molecular Pathology Research Group, * Department of Medical Biology, Faculty of Health Sciences, University of Troms $\phi$, Troms $\phi ;$; the Department of Radiology, ${ }^{\dagger}$ University Hospital of North Norway, Troms $\phi$; and the Norwegian Center for Molecular Medicine, ${ }^{\ddagger}$ University of Oslo, Oslo, Norway

\author{
Accepted for publication \\ June 30, 2016. \\ Address correspondence to Ole \\ P. Rekvig, M.D., Ph.D., RNA \\ and Molecular Pathology \\ Research Group, Department of \\ Medical Biology, Faculty of \\ Health Sciences, University of \\ Troms $\varnothing$, N-9037 Troms $\emptyset$, \\ Norway. E-mail: olepr@ \\ fagmed.uit.no.
}

\begin{abstract}
Divergent incommensurable models have been developed to explain the pathogenesis of lupus nephritis. Most contemporary models favor a central role for anti-chromatin antibodies. How they exert their pathogenic effect has, however, endorsed conflicts that at least for now preclude insight into definitive pathogenic pathways. The following paradigms are contemporarily in conflict with each other: $i$ ) the impact of anti-double-stranded DNA (dsDNA) antibodies that cross-react with inherent renal antigens, ii) the impact of anti-dsDNA antibodies targeting exposed chromatin in glomeruli, and iii) the impact of relative antibody avidity for dsDNA, chromatin fragments, or crossreacting antigens. Aside from these three themes, the pathogenic role of $T$ cells in lupus nephritis is not clear. These different models should be tested through a collaboration between scientists belonging to the different paradigms. If it turns out that there are different pathogenic pathways in lupus nephritis, the emerging pathogenic mechanism(s) may be encountered with new individual causal therapy modalities. Today, therapy is still unspecific and far from interfering with the cause(s) of the disorder. This review attempts to describe what we know about processes that may cause lupus nephritis and how such basic processes may be affected if we can specifically interrupt them. Secondary inflammatory mechanisms, cytokine signatures, activation of complement, and other contributors to inflammation will not be discussed herein; rather, the events that trigger these factors will be discussed. (Am J Pathol 2016, 186: 2772-2782; http://dx.doi.org/10.1016/ j.ajpath.2016.06.026)
\end{abstract}

\section{Pathogenesis-Background and Present Status}

Lupus nephritis represents the arrowhead among pathogenic manifestations in systemic lupus erythematosus (SLE) ${ }^{1-4}$ because it is dangerous, but also because it is scientifically challenging to comprehend its nature. ${ }^{1,5-7}$ This situation prevents us from developing therapy strategies that attack the basic pathogenic processes beyond today's therapy regimens. ${ }^{8-10}$ In the upcoming sections, contemporary status of the pathogenesis of SLE and lupus nephritis will be reviewed and discussed, and new causal therapy modalities will be suggested.

\section{Pathogenesis of the Autoimmune Syndrome SLE-A Central Role for Anti-dsDNA Antibodies?}

One central element when we discuss pathogenic processes in SLE is antibodies to double-stranded DNA (dsDNA) and chromatin structures. Anti-DNA antibodies were, however, first described in 1938 to 1939 in patients with

\footnotetext{
Supported by the University of Troms $\emptyset$ as Milieu Support (O.P.R.) and a Norwegian Center for Molecular Medicine, University of Oslo grant.

Disclosures: None declared.
} 
infections, ${ }^{11-14}$ as reviewed by Rekvig. ${ }^{15}$ Approximately two decades later, they were described in the autoimmune syndrome SLE. ${ }^{16-19}$ Since then, their role in SLE, rather than in infections and malignancies, ${ }^{15}$ has been extensively studied in two contexts: diagnostics and pathogenicity. ${ }^{15}$ However, the pathogenesis of SLE is still poorly understood, ${ }^{20,21}$ and may even remain unclear because SLE, as classified today, is not linked to any unifying origin or pathogenic process. In fact, if we use the 1982 American College of Rheumatology classification criteria, ${ }^{22}$ and classify SLE by randomly selecting 4 of these 11 defined American College of Rheumatology criteria (a minimum requirement to classify a disease as SLE, according to Tan et $\mathrm{al}^{22}$ ), theoretically 330 different clinical phenotypes embrace the term SLE. Does this mean that we, in fact, are dealing with a pile of unrelated disorders and manifestations that today is called SLE - and can we define biomarkers for SLE on this basis?

Recently, Pisetsky ${ }^{23}$ characterized anti-dsDNA antibodies as quintessential biomarkers for SLE. In light of the heterogenic image of SLE, and also because anti-dsDNA antibodies occur at various frequencies in different forms of cancers ${ }^{24,25}$ and infections, ${ }^{15}$ the statement that anti-dsDNA antibodies serve as a quintessential biomarker for SLE is difficult to comprehend. In fact, the first successful experiments that resulted in induction of anti-mammalian $\mathrm{B}$ helical (dsDNA) were performed by immunizing mice with dsDNA/ chromatin fragments in complex with a peptide from Trypanosoma cruzii (Fus $1^{26}$ ), or with a complex of polyomavirus $\mathrm{T}$ antigen and dsDNA/chromatin fragments (Figure 1A). The experimental details for this model have been described previously. ${ }^{27,28}$ In this experimental context, it is worthwhile to remember that the first discovery of anti-dsDNA antibodies in a natural context was achieved in sera from patients with bacterial infections six decades before the successful immunization experiments with complexes of mammalian chromatin and infectious-derived peptides, ${ }^{11-14}$ and also two decades before their discovery in SLE. ${ }^{15}$ Later, data demonstrating that pure chromatin fragments by themselves have the potential to induce diverse antibodies to chromatin have been demonstrated. These may represent antibodies to dsDNA, histones, non-histones, and complex determinants. The cellular processes responsible for these responses are, however, still poorly understood, ${ }^{15}$ although they are

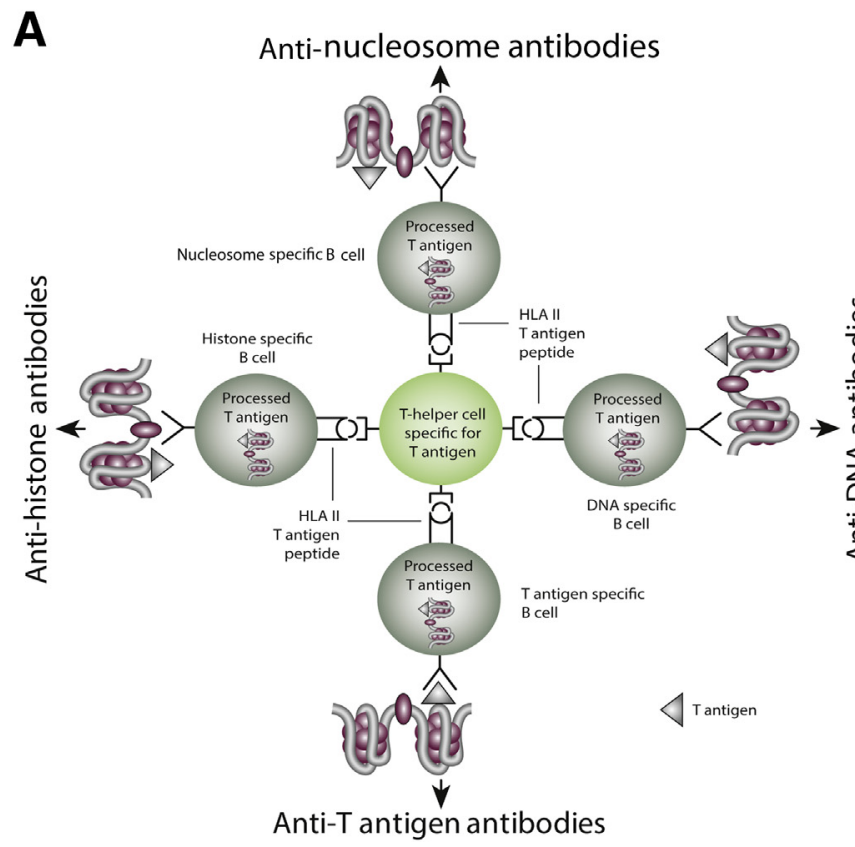

B

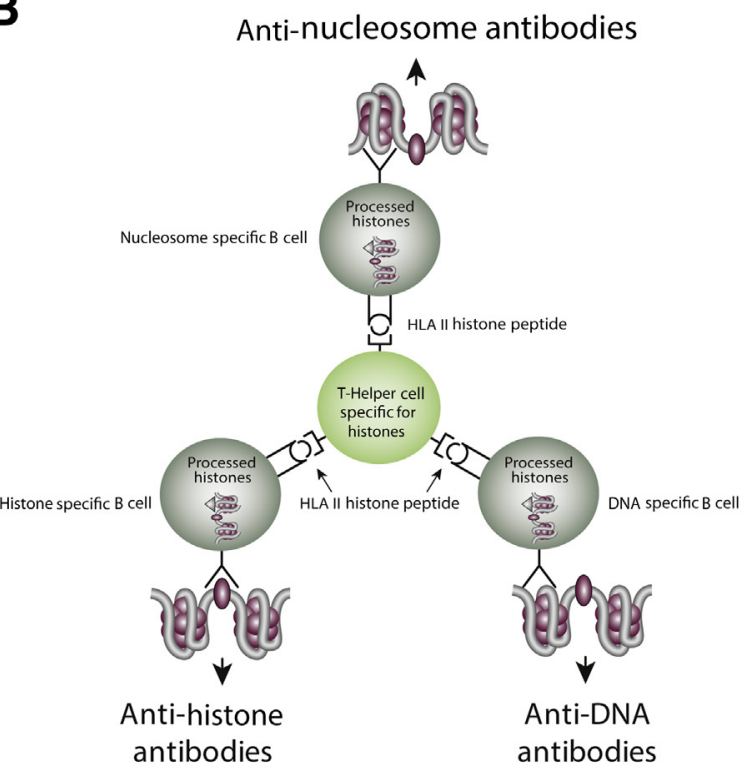

Figure 1 Cognate interaction of nucleosome-specific B cells and infectious-derived (A) or autoimmune-derived (B) peptide-specific T cells. The figure presents classic hapten-carrier-like models to explain linked production of chromatin-reactive antibodies. A: In this model, chromatin plays the role as a hapten, whereas heterologous (infectious-derived DNA-binding proteins like polyomavirus large T antigen) peptides play the role as carrier protein. In this model, primed T cells recognize T-antigen-derived peptides presented by B cells specific for different nucleosome structures. This model describes two features typical for systemic lupus erythematosus (SLE), production of affinity-maturated anti-dsDNA antibodies and linked production of antibodies to dsDNA, histones, and nonhistone chromatin-associated proteins. However, in this context, the individual may not at all experience SLE-rather the individual may experience infection. The principal paradigm for the hapten-carrier models presented in this figure is based on strong experimental evidence (see Pathogenesis of the Autoimmune Syndrome SLE-A Central Role for Anti-dsDNA Antibodies? for details). B: A hapten-carrier-like model is presented where chromatin represent the hapten, whereas chromatin-derived peptides represent the carrier protein. At difference from the model in $\mathbf{A}$, $\mathbf{T}$-cell tolerance to nucleosomes is terminated. As in $\mathbf{A}$, this model also describes linked production of antibodies reactive with chromatin constituents. In this situation, $\mathrm{T}$ cell tolerance to nucleosomal proteins is terminated, and the immune response is truly autoimmune. The cognate interaction of chromatin-specific $B$ cells and immune (A) or autoimmune (B) peptide-specific T cells may explain the origin of the comprehensive repertoire of chromatin-reactive IgG antibodies in human patients. Used with permission from Springer Science and Business Media. ${ }^{21} \mathrm{HLA}$, human leukocyte antigen. 
assumed to be based on a T-cell-dependent immune response, as indicated in Figure 1B.

The recent Systemic Lupus International Collaborating Clinics criteria did not solve this problem. ${ }^{29}$ Experts on SLE implemented clinical and laboratory parameters based on their individual insight, experience, clinical data, and intuition. ${ }^{29}$ These criteria therefore represent empirical, rather than scientific, approaches to understand SLE. From this, we cannot deduce the pathogenesis of lupus nephritis from the indistinct and poorly described pathogenesis of SLE per se. If lupus nephritis is one distinct disorder or not is presently unclear, and is discussed below.

\section{Lupus Nephritis-A Single Disease Entity?}

Theoretically, the approach to study the basic disease pathogenesis of lupus nephritis has a greater probability to succeed than to perform similar studies on the syndrome SLE.

However, there is currently no obvious reason to be optimistic because incommensurable models and contradicting data yet preclude international consensus. It is imperative to initiate new collaborations across the different models and paradigms to prepare consensus study protocols to solve the problem whether lupus nephritis is one disease entity with a dominant pathogenesis, or whether different pathogeneses are based on different incommensurable hypotheses, as indicated in Figure 2. The contemporary models of lupus nephritis are dependent on scientific interpretations of experimental data that emerge from different hypotheses. For each hypothesis, study protocols are selected and tailored to optimally analyze the validity of hypotheses. A theoretical model of these conflicting hypotheses and data sets is shown in Figure 2. The emerging concepts and models developed from divergent hypotheses are clearly visible in the conflicting interpretations of the pathogenesis, as described by one set of researchers ${ }^{6,7}$ versus another set of researchers. ${ }^{1,2,30}$ The following discussion has one perspective: to define lupus nephritis pathogenesis and key points for specific, causal therapy strategies.

\section{Pathogenesis of Lupus Nephritis-Incommensurable Models}

There are no unifying concepts available to explain lupus nephritis as it appears in murine models or in humans with SLE. Some recently reviewed concepts ${ }^{1,7}$ claim that anti-dsDNA antibodies are pathogenic because they recognize exposed chromatin in the mesangium or in glomerular basement membrane (Figure 3A). Others indicate that antibodies target cross-reacting antigens that appear as normal constituents in glomeruli ${ }^{1,15}$ (Figure 3B), or that chromatin-IgG complexes derive from circulation. ${ }^{31-33}$ These models may be valid irrespective of whether the antibodies are induced by

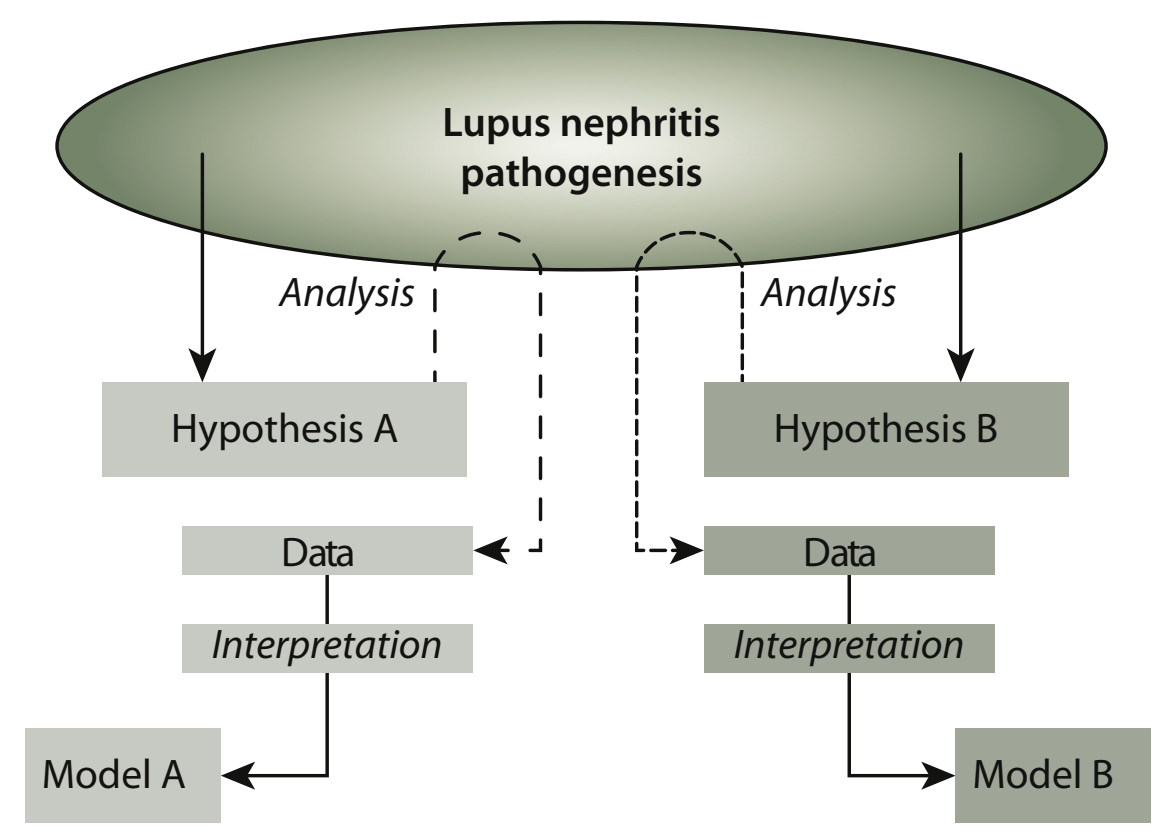

Figure 2 Studies of a defined biological problem, like a disease pathogenesis, may result in incommensurable models. The study object, in our context lupus nephritis, promotes testable hypotheses to describe its pathogenesis. In the left part of the figure, a hypothesis $A$ is developed, and it is tested by a strategy assumed to be relevant for the study. Then, the emerging data are interpreted, and translated into a pathogenic model $A$. In another context, the same study object may promote an alternative hypothesis, hypothesis B (right part of the figure). This alternative hypothesis is analyzed by another strategy still assumed to be relevant to solve the problem. Again, data are analyzed and interpreted as being a pathogenic model $B$. The realities of model A and model $B$, although intended to describe the same study object, differ in facts and consequences. Therefore, facts described in one experimental context cannot exclude that facts are somewhat different in another experimental context, although both models ( $A$ and $B$ ) are generated to solve the same problem. Thus, the incommensurable models $A$ and $B$ may promote further studies, but they may also split and disorganize scientific approaches in a way that hampers consensus. This relates also to the realities emerging from studies of the pathogenesis of lupus nephritis. 
A

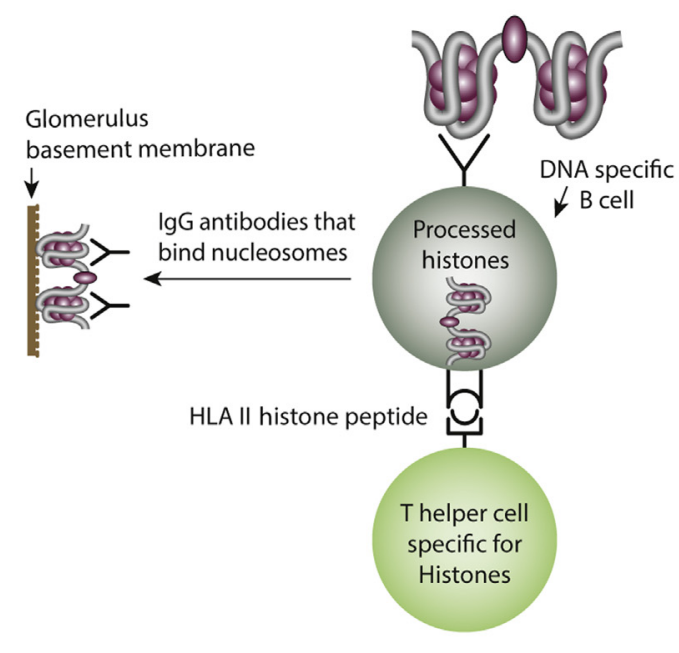

C

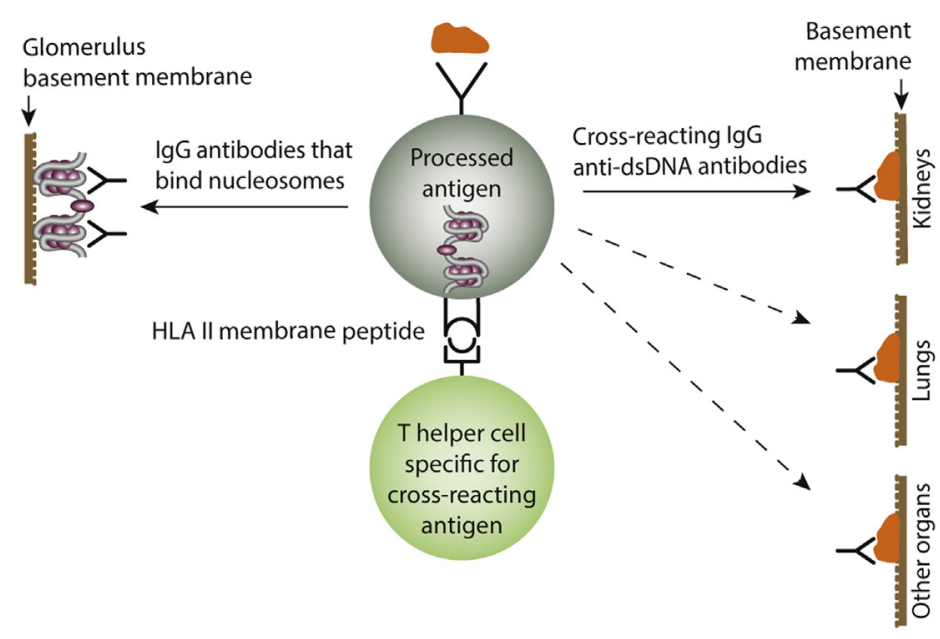

B

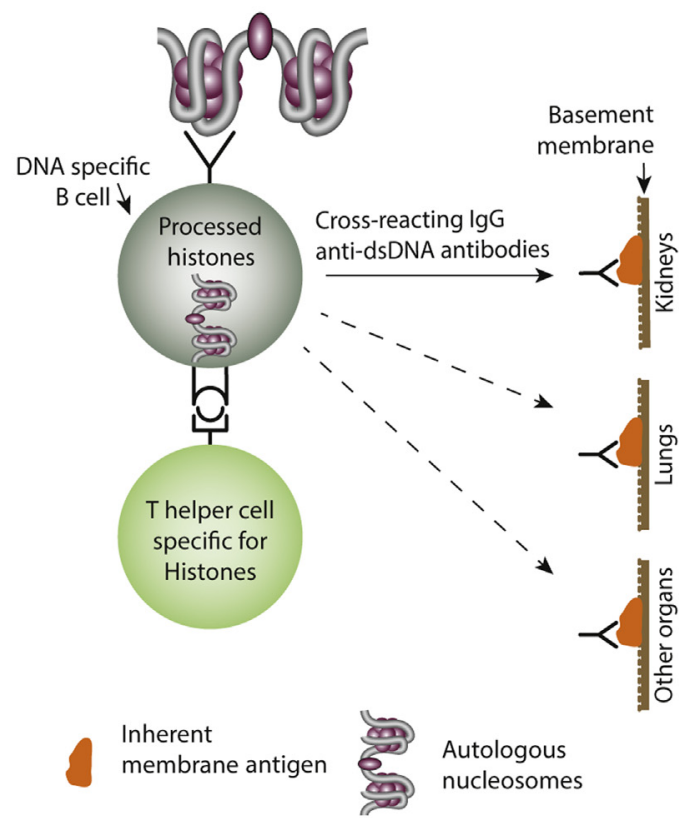

Figure 3 Pathogenicity of anti-dsDNA antibodies-do they target chromatin fragments or cross-reactive renal antigens? In A, DNAspecific $B$ cells are stimulated by chromatin fragments and histonespecific $T$ helper cells. The emerging anti-dsDNA antibodies bind exposed chromatin in glomeruli and initiate lupus nephritis. In this context, antibodies bind their homologous antigen(s). In B, the B and $T$ cells are stimulated by chromatin. The emerging antibodies cross-react with normal inherent structures in glomeruli, and may induce a type II immune-mediated renal inflammation. Whether this inflammation is restricted to kidneys (solid line in B), or may also occur in lungs or other organs (dotted lines in B), in analogy to anticollagen IV antibodies in Goodpasture syndrome, has not yet been investigated, but is principally possible. This is particularly relevant for anti-dsDNA antibodies that cross-react with laminin or entactin (see A Possible Role of Cross-Reacting Anti-dsDNA Antibodies in Lupus Nephritis for details). In C, the B cells specific for an inherent glomerular structure, like laminin or entactin, respond by producing cross-reactive anti-dsDNA/anti-chromatin antibodies. These antibodies may bind exposed chromatin fragments (C, left side) or homologous, inherent antigens in kidneys, lungs, and other organs (C, right side). In both situations, inflammation may be initiated, either as a type III immune-mediated renal inflammation (A) or as a type II immune-mediated renal inflammation (B). HLA, human leukocyte antigen. chromatin fragments (Figure 3, A and B) or by a crossreactive antigen (Figure $3 \mathrm{C}$ ).

In the first model, we need to know the role of the dominant renal endonuclease DNase I in lupus nephritis because renal DNase $\mathrm{I}$ is almost completely lost during disease progression. ${ }^{1,34,35}$ This seems to reduce clearance of chromatin from dead cells, and to promote harmful accumulation of undigested chromatin in glomeruli, which are targeted by chromatin-reactive IgG antibodies, either in situ or in circulation. ${ }^{1,34,35}$ In the second model, we need not to worry about extracellular chromatin and renal chromatin metabolism, because the antibodies are claimed to bind inherent renal structures.

\section{Low Proportion of Anti-dsDNA Antibodies among Antibodies Eluted from Nephritic Kidneys - What Does That Tell Us?}

In several studies, ${ }^{7,36-38}$ antibodies have been eluted from nephritic kidneys, and the relative amount of anti-dsDNA antibodies has been calculated to comprise up to $20 \%$ of the total eluted $\mathrm{IgG}^{39}$ This may indicate that dominant amounts 


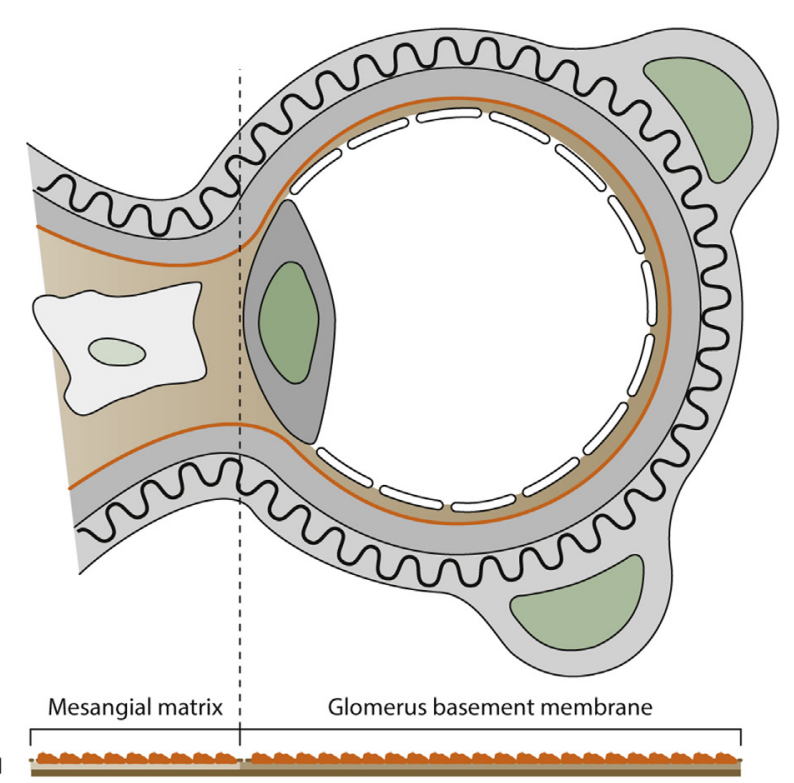

Mesangial nephritis by chromatin-IgG complexes

\section{人od $\lambda$ 人}

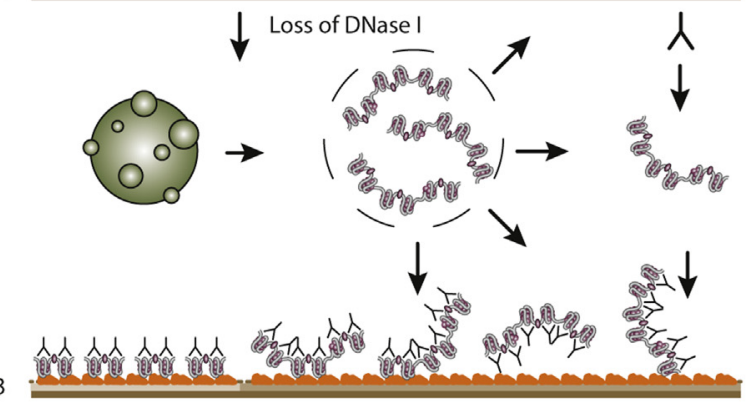

Lupus nephritis by chromatin-IgG complexes

4

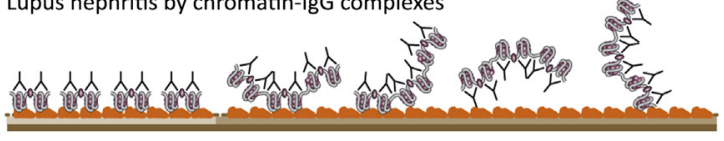

Lupus nephritis by cross-reacting antibodies

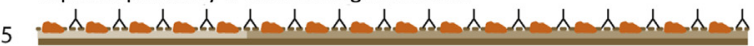

Goodpasture syndrome

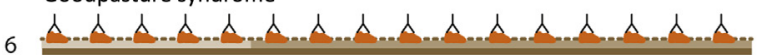
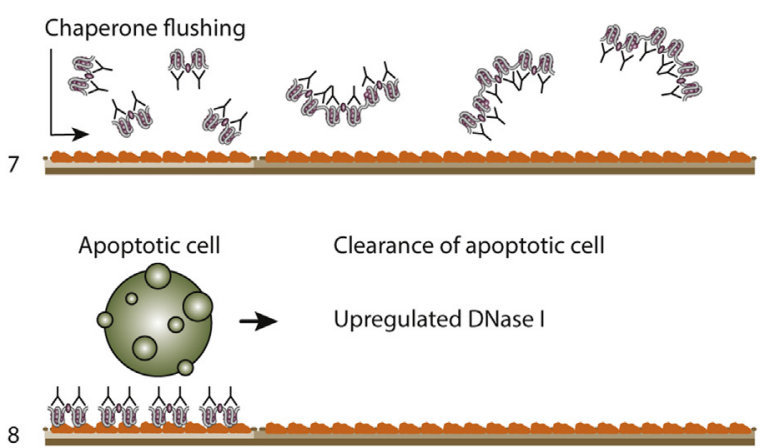

of IgG bind non-dsDNA antigens, like inherent renal antigens, or antigens released from resident cells. ${ }^{7,38-40}$

A sound basis to discuss these assumptions and observations derives from an article published by Craft and $\operatorname{Hardin}^{41}$ in 1987: "Linked sets of antinuclear antibodies: what do they mean?" The meaning could be that complex structures, like chromatin, simultaneously stimulate B cells specific for individual components or complex structures presented by chromatin fragments. This would explain linked production of potentially large arrays of antichromatin antibodies other than those uniquely specific for dsDNA $^{15}$ (Figure 1).

This idea was tested in our laboratory by injecting plasmids expressing the chromatin-binding polyomavirus BK large $\mathrm{T}$ antigen. ${ }^{27,28}$ Our prediction was that expressed $\mathrm{T}$ antigen bound host cell chromatin, and that chromatin- $\mathrm{T}$ antigen complexes were released from dying cells. Subsequently, they could stimulate a large repertoire of chromatin-specific B cells, and T-antigen peptide-specific $\mathrm{T}$ helper cells. ${ }^{27,28}$ The prediction was correct, as plasmidinjected mice simultaneously produced various antibodies to DNA, histones, and transcription factors in addition to $\mathrm{T}$ antigen in a timely linked manner (Figure 1A). This model is not fully dependent on non-self-proteins to activate non-tolerant $\mathrm{T}$ helper cell. As indicated in Figure 1B, true autoimmune $\mathrm{T}$ helper cells (herein specific for histone peptides in the context of human leukocyte antigen II molecules) provide the same effect as T-antigen-specific $\mathrm{T}$ helper cells described above, which again may explain a simultaneous production of various anti-chromatin antibodies.

This indicates that among the IgG eluted from nephritic kidneys, some bind dsDNA $^{39}$ but also that an (yet undetermined) amount of eluted $\mathrm{IgG}$ may bind other

Figure $\mathbf{4}$ Individual models of lupus nephritis pathogenesis lead to divergent causal therapy modalities. The principal structure of a glomerulus is presented with the mesangium on the left side and glomerulus basement membrane on the right side. Line 1 represents a glomerulus section seen from the side. In line 2, complexes of chromatin fragments and IgG accumulate in the mesangial matrix as part of early nephritis. Mesangial nephritis is followed by down-regulation of renal DNase I, which promotes a dramatic progression of the disease, with accumulation of large chromatin fragments in complex with IgG in glomerular basement membrane (GBM; line 3). Because of loss of DNase I enzyme activity, chromatin from secondary necrotic cells is not appropriately degraded and accumulates instead in GBM in complex with IgG (line 4). In contrast to the model depicted in lines 2 to 4 , anti-dsDNA antibodies may bind directly to components of the mesangial matrix and GBM (line 5). This would be equivalent to the binding of antibodies to collagen IV in glomeruli in context with Goodpasture syndrome (demonstrated in line 6). The chromatin model (lines 2 to 4 ) gives hints to causal, aim-directed therapy modalities. One approach is to elute chromatin-IgG complexes from the membranes by flushing the kidneys with chaperone molecules (line 7, see Future Therapy-A Perspective). This procedure has been shown to be beneficial for both mesangial as well as progressive lupus nephritis. A causal approach to treat progressive lupus nephritis may be to prevent loss of renal DNase I in the kidneys. This intervention would result in clearance of chromatin fragments from dead and dying cells (line 8). The cross-reactive model will most likely not be affected by these therapeutic approaches. 
components of chromatin that are not tested for in the referred studies (Figure 3). Therefore, low proportions of eluted anti-dsDNA antibodies can theoretically not represent an argument for a dominant presence of non-chromatinspecific cross-reactive IgG antibodies. However, if some of these antibodies really are cross-reacting, this does not inform about the potential target antigens that really bound the antibodies in vivo (see below for further discussion of this problem).

\section{Renal Targets for Nephritogenic Anti-DNA Antibodies-A Scientific Dilemma}

Two models have been developed that might explain the nephritogenic effect of anti-dsDNA antibodies. These are discussed in detail below.

\section{A Possible Role for Exposed Chromatin in Lupus Nephritis}

Clearance capacity of apoptotic cells is claimed to be reduced in SLE. ${ }^{42-44}$ This is assumed to be harmful because chromatin is not cleared, but instead chromatin fragments, consisting of the basic nucleosome structure and a vast amount of non-histone proteins and RNA molecules, ${ }^{45,46}$ bind glomerular laminin and collagen by fairly high affinities. ${ }^{47-49}$ This is consistent with successive accumulation of chromatin fragments in the mesangial matrix and glomerular basement membrane in vivo ${ }^{34}$ (Figure 4), as shown by the following studies.

By immune electron microscopy analyses applied to kidneys from mice and humans with lupus nephritis, we hardly observed lupus nephritis in absence of electron-dense structures $^{1}$ in the mesangial matrix, typical for mesangial nephritis, and in glomerular basement membrane, typical for membranoproliferative nephritis, respectively. ${ }^{50,51}$ These electron-dense structures were first described more than three decades ago, and at that time linked to lupus nephritis. ${ }^{52-54}$ Detailed analyses revealed that electron-dense structures contained chromatin fragments, as indicated by detection of terminal deoxy-nucleotidyl transferase dUTP nick end labeling-positive DNA, histones, and transcription factors. ${ }^{50,51}$ These chromatin fragments colocalized with in vivo-bound $\mathrm{IgG}$. In vivo binding of $\mathrm{IgG}$ directly to regular glomerular basement membrane and matrix structures, which could indicate a cross-reaction with normal membrane/matrix structures, was not observed during these analyses. ${ }^{15,50}$

The progression of the disease coincided with a nearby complete loss of renal DNase I gene expression and endonucleolytic activity. ${ }^{34,35,55,56}$ The expression of renal DNase $I$ gene was selectively down-regulated among renal genes examined, and only in kidneys and not in other organs. ${ }^{35}$ DNase I constitutes $>80 \%$ of the total renal endonuclease activity. Accordingly, loss of this endonuclease resulted in accumulation of large chromatin fragments in glomeruli, and correlated in time with progressive renal inflammation. ${ }^{35,50,57}$ Thus, chromatin-IgG complexes may be involved in both early and late stages of lupus nephritis. This contrasts the nephritic processes possibly induced by cross-reactive anti-dsDNA antibodies.

\section{A Possible Role of Cross-Reacting Anti-dsDNA Antibodies in Lupus Nephritis}

Another aspect that was considered to be important in the pathogenesis of lupus nephritis was the promiscuous tendency of anti-dsDNA antibodies to cross-react with non-DNA structures. ${ }^{30,58-60}$ This could imply that antidsDNA antibodies have the potential to cross-react with intrinsic renal structures.

Why Did Cross-Reactivity Become a Focus in a Search for the Pathogenesis in Lupus Nephritis?

This idea evolved decades ago when scientists tried to understand the molecular and cellular origin of anti-dsDNA antibodies. During the 1970s and 1980s, target structures for naturally and/or experimentally induced anti-DNA antibodies were described, like double-stranded Z-DNA, natural and synthetic single-stranded DNA and dsDNA sequences, bent and elongated dsDNA, cruciform structures, RNA-DNA hybrid double strands, and mammalian B-helical dsDNA. ${ }^{61-64}$

At the same time, scientists tried to understand if molecules with a certain degree of mimicry to DNA could induce anti-dsDNA antibodies, ${ }^{65-68}$ because mammalian dsDNA itself was considered nonimmunogenic. ${ }^{63,69}$ Indeed, many cross-reactions between DNA and non-DNA structures have been described. ${ }^{15,30}$ Thus, cross-reaction may have a twofold meaning in this context: an idea to understand the origin of cross-reactive anti-dsDNA antibodies that transformed into the idea to understand the role of cross-reacting antibodies in the pathogenesis of lupus nephritis.

Anti-dsDNA antibodies cross-react with a large spectrum of antigens to intracellular structures, renal cell membranes, or extracellular matrices. ${ }^{15,30} \mathrm{~A}$ common denominator for many of these studies is that anti-dsDNA antibodies bind inherent glomerular antigens whether they are part of membranes and matrices or released from resident renal cells. ${ }^{1,30}$

\section{Relative Avidity for the Structures Recognized by Nephritogenic Antibodies-Theoretical Thoughts}

\section{The Intrinsic Characteristics of Anti-dsDNA Antibodies}

When we discuss the role of intrinsic affinity, avidity, and specificity of an anti-dsDNA antibody, we traditionally do not consider whether high or low avidity relates to 
cross-reactivity between different DNA structures that are present in chromatin, or between DNA and non-DNA structures. We have not taken into account what is known among basic scientists who analyze DNA structures like elongated or highly bent B-helical or Z-helical dsDNA ${ }^{70,71}$ within chromatin or in protein-free DNA. ${ }^{15}$ Therefore, it is wise to consider what we mean by the term avidity applied to anti-dsDNA antibodies.

\section{Avidity}

A formal definition of avidity in the context of ligand interactions is the accumulated strength of multiple affinities of noncovalent binding interactions between a polyvalent structure and a polyvalent ligand. Thus, avidity is distinct from intrinsic affinity, which describes the strength of a single, monovalent interaction like the molecular forces involved in monomeric Fab-epitope interactions. $^{72,73}$ Avidity is therefore the accumulated strength of multiple affinities and is much stronger than the sum of individual monomeric intrinsic affinities. How does this translate into the understanding of avidity in the context of anti-dsDNA antibodies and lupus nephritis?

This problem is complicated by the fact that antibody specificity and avidity are not well-defined entities. Mammalian dsDNA comprises different structures, like single-stranded (ss)DNA regions, Z-DNA, highly bent or elongated mammalian B-helical DNA, and cruciform structures. ${ }^{61,62,64} \mathrm{~B}$ cells recognize these structures with high precision. ${ }^{15,69,74,75}$ This may also mean that if an anti-dsDNA antibody is induced by elongated nucleosomal linker dsDNA, this will represent the specificity of that given immune response - and it may be of high avidity.

Assume that this antibody cross-reacts with bent dsDNA as in the Crithidia kinetoplast or in a plasmid used in Farr assays, and, if they are not heteroclitic, ${ }^{76}$ the avidity may be lower. Does then this antibody have a phenomenologically high avidity (for elongated dsDNA) or low avidity (for cross-reactive bent dsDNA)?

That an antibody bind in high salt, as in the Farr assay, may not at all relate to avidity. The latter assumption derives from the fact that antibodies against Z-DNA, but not B-DNA, bind at high salt ( 2 to $4 \mathrm{~mol} / \mathrm{L} \mathrm{NaCl}){ }^{77,78}$ Thus, it is not clear whether antibodies that bind DNA in the Farr assay possess unique specificity for DNA structures shaped in high salt concentration, or have a high avidity. An overview of the forces involved in antibody-antigen interactions has previously been published. ${ }^{73}$

It is in the context important to make clear that many antibodies, when binding chromatin, will bind to the DNA structure that fits best, because chromatin fragments present the whole universe of mammalian DNA structures. ${ }^{45}$ Therefore, an antibody that binds in an enzyme-linked immunosorbent assay, but not in Farr, may still have a high avidity for its target antigen-exposed chromatin structures.

From this, one may assume that all kinds of anti-dsDNA antibodies reactive with mammalian dsDNA as part of chromatin may be pathogenic, independent of the magnitude of avidity or intrinsic affinity as long as they bind accessible dsDNA in chromatin fragments like those exposed in kidneys in the context of lupus nephritis. ${ }^{15}$

Likewise, we do not know whether anti-dsDNA antibodies cross-react with renal antigens with high avidity, or at lower avidity than toward dsDNA in chromatin fragments. Their relative avidities may in fact direct the antibodies toward the structures recognized by the highest relative avidity. This may question whether heterologous (cross-reactive) or homologous (recognition of chromatin) binding of the antibodies determines their pathogenic impact.

\section{Pathogenesis of Lupus Nephritis Linked to Cross-Reactive Anti-dsDNA Antibodies and to Chromatin Autoimmunity-Facts and Problems}

Several models are generated to understand lupus nephritis, and they are all easy to comprehend. However, each model raises problems that need to be solved, preferentially by collaboration across the models.

\section{The Cross-Reactive Model-Facts and Problems}

There is no doubt that anti-dsDNA antibodies cross-react with structurally unrelated renal antigens ${ }^{15,30,61}$ (see also the thoughtful review by Goilav and Putterman ${ }^{7}$ ). However, several problems that may hamper the understanding of the effect of cross-reactive anti-dsDNA antibodies can be identified. Therefore, further investigations are required. For example, there is a tendency that each scientific report focuses on a new cross-reacting antibody without emphasizing the impact of the other reported cross-reactive antibodies in comparative studies.

Theoretically, the cross-reactive pattern of an antidsDNA antibody may not prevail in the body when the immune responses affinity maturate. The heavy and light chain V-region structures are degenerate and structurally unstable. ${ }^{15,79,80}$ This implies that over time, the specificity may converge toward the immunogen with loss of cross-specificity ${ }^{15,80}$ because of stochastic somatic mutations.

Furthermore, is antibody avidity for the cross-reacting antigens (eg, dsDNA and entactin) similar? Will the highest avidity direct the antibodies to chromatin or to the renal antigen?

Relevant to the latter question is whether antibodies monospecific for the non-DNA cross-reacting antigen will bind in glomeruli on injection as, for example, purified biotinylated IgG antibodies? This experiment will inform 
whether antibodies to cross-reactive non-DNA antigens can bind in vivo in a way similar as the Goodpasture-related anticollagen IV antibody. In many of the studies referred to above, antibodies bound in vivo in glomeruli were not eluted from kidney specimens. A central question in this context will consequently be whether a cross-reactive antibody population is present in the eluates, and whether the relative avidities for dsDNA and the cross-reactive antigen differ in magnitude. If so, high avidity for one of the ligands may in fact point at targeted antigen in vivo. For example, we observed that antibody avidity for dsDNA was higher in the eluted antibody population compared to the antibodies in circulation. ${ }^{81}$

In analogy to the pathogenesis of Goodpasture syndrome, where antibodies to collagen IV bind in basement membranes in glomeruli and alveoli, ${ }^{82}$ one may question whether antibodies that cross-react between dsDNA and laminin or entactin (see above) bind such antigens exposed in other organs (Figure 3B). There is some precedence for this model, ${ }^{83}$ although deposits in the lungs were not analyzed in that study. This has, to our knowledge, not been investigated so far. Theoretically, antibodies that cross-react with dsDNA and laminin or entactin may bind in other organs where such structures are accessible.

If the cross-reactive antibody is the pathogenic factor in lupus nephritis, how should we then explain their role after successful treatment, when the kidneys restore their function while antibodies remain in circulation even at high titers $?^{84,85}$ An alternative explanation would be that target structures for the antibodies (like chromatin) were cleared.

\section{The Chromatin Model-Facts and Problems}

There is no doubt that chromatin in complex with $\operatorname{IgG}$ is exposed in glomeruli during lupus nephritis. ${ }^{34,50,86,87}$ In that form, chromatin-IgG complexes initiate severe inflammation, as in lupus nephritis. Still, however, several theoretical problems are connected with this pathogenic model. What is the origin of extracellular chromatin, and why is chromatin exposed and accumulated in glomeruli? The indirect cause may be silencing of the renal DNase I gene expression, ${ }^{35}$ which consequently may cause local accumulation of extracellular chromatin that binds glomerular membranes and matrices with high affinity, irrespective of whether in complex with IgG anti-chromatin antibodies or not. ${ }^{47} \mathrm{We}$ do not know the basis for the process that accounts for silencing of the DNase I gene expression. However, preliminary data may indicate that glomerular exposed chromatin derives from resident glomerular cells (studies in progress).

\section{Future Therapy - A Perspective}

Today, therapeutic intervention in lupus nephritis is not specific and not causal (several studies ${ }^{8,88,89}$ provide an update on current therapy modalities). Before we can develop causal strategies, we need to know the basic, responsible pathogenic mechanism(s) in lupus nephritis. Figure 4 provides principals of the different models and possible development of causal therapy modalities. We can achieve this if scientists collaborate across the different models to determine which the correct ones are. If, for example, the exposed chromatin model is correct, then an obvious approach would be to promote up-regulation of the renal DNase $I$ gene to increase clearance of chromatin in dying cells (Figure 4). It is, however, not sufficient to inject DNase I because intravenous or subcutaneous administration of DNase I has a limited effect, ${ }^{35}$ probably because chromatin bound to membranes is relatively nuclease resistant. ${ }^{1}$ This would not protect against mesangial nephritis, but against progression of the disease (Figure 4).

The reason why extracellular DNase I may not be effective for degradation of extracellular chromatin could be explained as follows. First, chromatin possesses a fairly high affinity for laminin and collagens. ${ }^{47,48}$ Second, extrapolating from information provided by DNase footprinting assays, ${ }^{90,91}$ the interaction of chromatin/dsDNA with proteins may protect chromatin from being enzymatically degraded.

Another approach would be to increase degradation of extracellular chromatin, and to prevent binding of chromatin-IgG complexes to membranes and matrices by infusing chaperone molecules like heparin. For example, heparin has the potential to inhibit binding of chromatin to membrane structures in vitro and in vivo, and to make the chromatin structure more sensitive to nucleases and proteases $^{92,93}$ (Figure 4).

If, on the other hand, cross-reaction of anti-dsDNA antibodies represents the basis for a pathogenic process, this may be treated with selected peptides from either of the specific determinants. A thoughtful discussion is provided by Monneaux and Muller ${ }^{94}$ and other researchers. ${ }^{95-97}$ If this approach is valid, we face the problem that many cross-reacting peptides are linked to lupus nephritis. Therefore, this therapeutic approach may represent a new version of individualized treatment.

\section{Conclusions}

Today, we are confronted with the situation that each of the described pathogenic mechanisms may both be true and both may explain lupus nephritis. However, they are not proved beyond doubt. It is in this context a problem that scientists confer themselves to their own hypotheses in an unreservedly subjective way. This generates the basis for incommensurable models. This critical comment relates to scientists involved in this research field, irrespective of which of the models they advocate: recognition of renal 
targets by cross-reaction or antibody recognition of exposed chromatin in the kidneys.

\section{Acknowledgments}

The authors thank Rod Wolstenholme (Section for Dissemination Services, Faculty of Health Sciences, University of Troms $\varnothing$ ) for expert help in preparing the figures, and Ingebrigt Sylte (Department of Pharmacology, Faculty of Health Sciences, University of Troms $\varnothing$ ) for calculations.

\section{References}

1. Seredkina N, van der Vlag J, Berden J, Mortensen E, Rekvig OP: Lupus nephritis: enigmas, conflicting models and an emerging concept. Mol Med 2013, 19:161-169

2. van Bavel CC, van der Vlag J, Berden JH: Glomerular binding of anti-dsDNA autoantibodies: the dispute resolved? Kidney Int 2007, 71:600-601

3. Weening JJ, D'agati VD, Schwartz MM, Seshan SV, Alpers CE, Appel GB, Balow JE, Bruijn JA, Cook T, Ferrario F, Fogo AB, Ginzler EM, Hebert L, Hill G, Hill P, Jennette JC, Kong NC, Lesavre P, Lockshin M, Looi LM, Makino H, Moura LA, Nagata M: The classification of glomerulonephritis in systemic lupus erythematosus revisited. J Am Soc Nephrol 2004, 15:241-250

4. Berden JH: Lupus nephritis. Kidney Int 1997, 52:538-558

5. Lorenz G, Desai J, Anders HJ: Lupus nephritis: update on mechanisms of systemic autoimmunity and kidney immunopathology. Curr Opin Nephrol Hypertens 2014, 23:211-217

6. Marion TN, Postlethwaite AE: Chance, genetics, and the heterogeneity of disease and pathogenesis in systemic lupus erythematosus. Semin Immunopathol 2014, 36:495-517

7. Goilav B, Putterman C: The role of anti-DNA antibodies in the development of lupus nephritis: an alternative, or complementary, viewpoint? Semin Nephrol 2015, 35:439-443

8. Anders HJ, Jayne DR, Rovin BH: Hurdles to the introduction of new therapies for immune-mediated kidney diseases. Nat Rev Nephrol 2016, 12:205-216

9. Mok CC: Treat-to-target in systemic lupus erythematosus: are we there yet? Expert Rev Clin Pharmacol 2016, 9:675-680

10. Mok CC: Towards new avenues in the management of lupus glomerulonephritis. Nat Rev Rheumatol 2016, 12:221-234

11. Menzel AEO, Heidelberger M: Cell protein fractions of bovine and avian tubercle bacillus strains and of the timothy-grass bacillus. J Biol Chem 1938, 124:301-307

12. Sevag MG, Lackman DB, Smolen J: The isolation of the components of streptococcal nucleoproteins in serologically active form. J Biol Chem 1938, 124:425-436

13. Winkenwerder WL, Buell MV, Howard JE: The sensitizing properties of the nucleic acids and their derivatives. Science 1939, 90: 356

14. Heidelberger M, Scherp HW: Protein fractions of a strain of Group "A" hemolytic streptococci. J Immunol 1939, 37:563-570

15. Rekvig OP: The anti-DNA antibody: origin and impact, dogmas and controversies. Nat Rev Rheumatol 2015, 11:530-540

16. Ceppellini R, Polli E, Celada F: A DNA-reacting factor in serum of a patient with lupus erythematosus diffusus. Proc Soc Exp Biol Med 1957, 96:572-574

17. Robbins WC, Holman HR, Deicher H, Kunkel HG: Complement fixation with cell nuclei and DNA in lupus erythematosus. Proc Soc Exp Biol Med 1957, 96:575-579

18. Miescher P, Strassle R: New serological methods for the detection of the L.E. factor. Vox Sang 1957, 2:283-287
19. Seligman M: Serology-evidence in serum from patients with disseminated lupus erythermatosus of a substance determining a precipitation reaction with desoxyribonucleic acid. C R Hebd Seances Acad Sci 1957, 245:243-245

20. Rahman A, Isenberg DA: Systemic lupus erythematosus. N Engl J Med 2008, 358:929-939

21. Rekvig OP, van der Vlag J: The pathogenesis and diagnosis of systemic lupus erythematosus: still not resolved. Semin Immunopathol 2014, 36:301-311

22. Tan EM, Cohen AS, Fries JF, Masi AT, McShane DJ, Rothfield NF, Schaller JG, Talal N, Winchester RJ: The 1982 revised criteria for the classification of systemic lupus erythematosus. Arthritis Rheum 1982, 25:1271-1277

23. Pisetsky DS: Anti-DNA antibodies: quintessential biomarkers of SLE. Nat Rev Rheumatol 2016, 12:102-110

24. Bei R, Masuelli L, Palumbo C, Modesti M, Modesti A: A common repertoire of autoantibodies is shared by cancer and autoimmune disease patients: inflammation in their induction and impact on tumor growth. Cancer Lett 2009, 281:8-23

25. Cao Q, Xu W, Wen Z, Xu L, Li K, Chu Y, Xiong S: An anti-doublestranded DNA monoclonal antibody induced by tumor cell-derived DNA inhibits the growth of tumor in vitro and in vivo via triggering apoptosis. DNA Cell Biol 2008, 27:91-100

26. Desai DD, Krishnan MR, Swindle JT, Marion TN: Antigen-specific induction of antibodies against native mammalian DNA in nonautoimmune mice. J Immunol 1993, 151:1614-1626

27. Moens U, Seternes OM, Hey AW, Silsand Y, Traavik T, Johansen B, Rekvig OP: In vivo expression of a single viral DNA-binding protein generates systemic lupus erythematosus-related autoimmunity to double-stranded DNA and histones. Proc Natl Acad Sci U S A 1995, 92:12393-12397

28. Rekvig OP, Moens U, Sundsfjord A, Bredholt G, Osei A, Haaheim H, Traavik T, Arnesen E, Haga HJ: Experimental expression in mice and spontaneous expression in human SLE of polyomavirus T-antigen: a molecular basis for induction of antibodies to DNA and eukaryotic transcription factors. J Clin Invest 1997, 99:2045-2054

29. Petri M, Orbai AM, Alarcon GS, Gordon C, Merrill JT, Fortin PR, et al: Derivation and validation of the Systemic Lupus International Collaborating Clinics classification criteria for systemic lupus erythematosus. Arthritis Rheum 2012, 64:2677-2686

30. van Bavel CC, Fenton KA, Rekvig OP, van der Vlag J, Berden JH: Glomerular targets of nephritogenic autoantibodies in systemic lupus erythematosus. Arthritis Rheum 2008, 58:1892-1899

31. Adu D, Dobson J, Williams DG: DNA-anti-DNA circulating complexes in the nephritis of systemic lupus erythematosus. Clin Exp Immunol 1981, 43:605-614

32. Fenton KA, Tommeras B, Marion TN, Rekvig OP: Pure anti-dsDNA mAbs need chromatin structures to promote glomerular mesangial deposits in BALB/c mice. Autoimmunity 2010, 43:179-188

33. Ehrenstein MR, Katz DR, Griffiths MH, Papadaki L, Winkler TH, Kalden JR, Isenberg DA: Human IgG anti-DNA antibodies deposit in kidneys and induce proteinuria in SCID mice. Kidney Int 1995, 48: 705-711

34. Fenton K, Fismen S, Hedberg A, Seredkina N, Fenton C, Mortensen ES, Rekvig OP: Anti-dsDNA antibodies promote initiation, and acquired loss of renal Dnase1 promotes progression of lupus nephritis in autoimmune (NZBxNZW)F1 mice. PLoS One 2009, 4:e8474

35. Seredkina N, Rekvig OP: Acquired loss of renal nuclease activity is restricted to DNaseI and is an organ-selective feature in murine lupus nephritis. Am J Pathol 2011, 179:1120-1128

36. Sabbaga J, Pankewycz OG, Lufft V, Schwartz RS, Madaio MP Cross-reactivity distinguishes serum and nephritogenic anti-DNA antibodies in human lupus from their natural counterparts in normal serum. J Autoimmun 1990, 3:215-235

37. Xie C, Liang Z, Chang S, Mohan C: Use of a novel elution regimen reveals the dominance of polyreactive antinuclear autoantibodies in lupus kidneys. Arthritis Rheum 2003, 48:2343-2352 
38. Kalaaji M, Sturfelt G, Mjelle JE, Nossent H, Rekvig OP: Critical comparative analyses of anti-alpha-actinin and glomerulus-bound antibodies in human and murine lupus nephritis. Arthritis Rheum 2006, 54:914-926

39. Mannik M, Merrill CE, Stamps LD, Wener MH: Multiple autoantibodies form the glomerular immune deposits in patients with systemic lupus erythematosus. J Rheumatol 2003, 30:1495-1504

40. Krishnan MR, Wang C, Marion TN: Anti-DNA autoantibodies initiate experimental lupus nephritis by binding directly to the glomerular basement membrane in mice. Kidney Int 2012, 82: 184-192

41. Craft JE, Hardin JA: Linked sets of antinuclear antibodies: what do they mean? J Rheumatol Suppl 1987, 14 Suppl 13:106-109

42. Biermann MH, Veissi S, Maueroder C, Chaurio R, Berens C, Herrmann M, Munoz LE: The role of dead cell clearance in the etiology and pathogenesis of systemic lupus erythematosus: dendritic cells as potential targets. Expert Rev Clin Immunol 2014, 10: $1151-1164$

43. Gaipl US, Voll RE, Sheriff A, Franz S, Kalden JR, Herrmann M: Impaired clearance of dying cells in systemic lupus erythematosus. Autoimmun Rev 2005, 4:189-194

44. Licht R, Dieker JW, Jacobs CW, Tax WJ, Berden JH: Decreased phagocytosis of apoptotic cells in diseased SLE mice. J Autoimmun 2004, 22:139-145

45. van Steensel B: Chromatin: constructing the big picture. EMBO J 2011, 30:1885-1895

46. de Graaf CA, van Steensel B: Chromatin organization: form to function. Curr Opin Genet Dev 2013, 23:185-190

47. Mjelle JE, Rekvig OP, Fenton KA: Nucleosomes possess a high affinity for glomerular laminin and collagen IV and bind nephritogenic antibodies in murine lupus-like nephritis. Ann Rheum Dis 2007, 66:1661-1668

48. Fismen S, Hedberg A, Fenton K, Jacobsen S, Krarup E, Kamper A, Rekvig O, Mortensen E: Circulating chromatin-anti-chromatin antibody complexes bind with high affinity to dermo-epidermal structures in murine and human lupus nephritis. Lupus 2009, 18: 597-607

49. Van Bruggen MC, Kramers C, Walgreen B, Elema JD, Kallenberg CG, van den Born J, Smeenk RJ, Assmann KJ, Muller S, Monestier M, Berden JH: Nucleosomes and histones are present in glomerular deposits in human lupus nephritis. Nephrol Dial Transplant 1997, 12:57-66

50. Kalaaji M, Mortensen E, Jorgensen L, Olsen R, Rekvig OP: Nephritogenic lupus antibodies recognize glomerular basement membraneassociated chromatin fragments released from apoptotic intraglomerular cells. Am J Pathol 2006, 168:1779-1792

51. Kalaaji M, Fenton KA, Mortensen ES, Olsen R, Sturfelt G, Alm P, Rekvig OP: Glomerular apoptotic nucleosomes are central target structures for nephritogenic antibodies in human SLE nephritis. Kidney Int 2007, 71:664-672

52. Ben-Bassat M, Rosenfeld J, Joshua H, Hazaz B, Gura V: Lupus nephritis: electron-dense and immunofluorescent deposits and their correlation with proteinuria and renal function. Am J Clin Pathol 1979, 72:186-193

53. Comerford FR, Cohen AS, Desai RG: The evolution of the glomerular lesion in NZB mice: a light and electron microscopic study. Lab Invest 1968, 19:643-651

54. Dillard MG, Tillman RL, Sampson CC: Lupus nephritis: correlations between the clinical course and presence of electron-dense deposits. Lab Invest 1975, 32:261-269

55. Seredkina N, Zykova SN, Rekvig OP: Progression of murine lupus nephritis is linked to acquired renal Dnase1 deficiency and not to up-regulated apoptosis. Am J Pathol 2009, 175:97-106

56. Zykova SN, Tveita AA, Rekvig OP: Renal Dnase1 enzyme activity and protein expression is selectively shut down in murine and human membranoproliferative lupus nephritis. PLoS One 2010, 10:5
57. Berden JH, Grootscholten C, Jurgen WC, van der Vlag J: Lupus nephritis: a nucleosome waste disposal defect? J Nephrol 2002, 15 Suppl 6:S1-S10

58. Brinkman K, Termaat R, Berden JH, Smeenk RJ: Anti-DNA antibodies and lupus nephritis: the complexity of crossreactivity [see comments]. Immunol Today 1990, 11:232-234

59. Eilat D: Cross-reactions of anti-DNA antibodies and the central dogma of lupus nephritis. Immunol Today 1985, 6:123-127

60. Mageed RA, Zack DJ: Cross-reactivity and pathogenicity of antiDNA autoantibodies in systemic lupus erythematosus. Lupus 2002, $11: 783-786$

61. Stollar BD: Immunochemistry of DNA. Int Rev Immunol 1989, 5: $1-22$

62. Stollar BD: Antibodies to DNA. CRC Crit Rev Biochem 1986, 20: $1-36$

63. Madaio MP, Hodder S, Schwartz RS, Stollar BD: Responsiveness of autoimmune and normal mice to nucleic acid antigens. J Immunol 1984, 132:872-876

64. Pisetsky DS, Vrabie IA: Antibodies to DNA: infection or genetics? Lupus 2009, 18:1176-1180

65. Lafer EM, Rauch J, Andrzejewski C Jr, Mudd D, Furie B, Furie B, Schwartz RS, Stollar BD: Polyspecific monoclonal lupus autoantibodies reactive with both polynucleotides and phospholipids. J Exp Med 1981, 153:897-909

66. Mostoslavsky G, Fischel R, Yachimovich N, Yarkoni Y, Rosenmann E, Monestier M, Baniyash M, Eilat D: Lupus anti-DNA autoantibodies cross-react with a glomerular structural protein: a case for tissue injury by molecular mimicry. Eur J Immunol 2001, 31: $1221-1227$

67. Putterman C, Diamond B: Immunization with a peptide surrogate for double-stranded DNA (dsDNA) induces autoantibody production and renal immunoglobulin deposition. J Exp Med 1998, 188:29-38

68. DeGiorgio LA, Konstantinov KN, Lee SC, Hardin JA, Volpe BT, Diamond B: A subset of lupus anti-DNA antibodies cross-reacts with the NR2 glutamate receptor in systemic lupus erythematosus. Nat Med 2001, 7:1189-1193

69. Stollar BD: Why the difference between B-DNA and Z-DNA? Lupus 1997, 6:327-328

70. Kornberg RD, Lorch Y: Twenty-five years of the nucleosome, fundamental particle of the eukaryote chromosome. Cell 1999, 98: 285-294

71. Luger K, Mader AW, Richmond RK, Sargent DF, Richmond TJ: Crystal structure of the nucleosome core particle at 2.8 A resolution [see comments]. Nature 1997, 389:251-260

72. Braden BC, Goldman ER, Mariuzza RA, Poljak RJ: Anatomy of an antibody molecule: structure, kinetics, thermodynamics and mutational studies of the antilysozyme antibody D1.3. Immunol Rev 1998, 163:45-57

73. Ros R, Schwesinger F, Anselmetti D, Kubon M, Schafer R, Pluckthun A, Tiefenauer L: Antigen binding forces of individually addressed single-chain Fv antibody molecules. Proc Natl Acad Sci U S A 1998, 95:7402-7405

74. Stollar BD: The antigenic potential and specificity of nucleic acids, nucleoproteins, and their modified derivatives. Arthritis Rheum 1981, 24:1010-1018

75. Jang YJ, Stollar BD: Anti-DNA antibodies: aspects of structure and pathogenicity. Cell Mol Life Sci 2003, 60:309-320

76. Chitarra V, Alzari PM, Bentley GA, Bhat TN, Eisele JL, Houdusse A, Lescar J, Souchon H, Poljak RJ: Three-dimensional structure of a heteroclitic antigen-antibody cross-reaction complex. Proc Natl Acad Sci U S A 1993, 90:7711-7715

77. Moller A, Gabriels JE, Lafer EM, Nordheim A, Rich A, Stollar BD: Monoclonal antibodies recognize different parts of Z-DNA. J Biol Chem 1982, 257:12081-12085

78. Lafer EM, Sousa R, Ali R, Rich A, Stollar BD: The effect of anti-Z-DNA antibodies on the B-DNA-Z-DNA equilibrium. J Biol Chem 1986, 261:6438-6443 
79. Odegard VH, Schatz DG: Targeting of somatic hypermutation. Nat Rev Immunol 2006, 6:573-583

80. Li Z, Woo CJ, Iglesias-Ussel MD, Ronai D, Scharff MD: The generation of antibody diversity through somatic hypermutation and class switch recombination. Genes Dev 2004, 18:1-11

81. Mjelle JE, Kalaaji M, Rekvig OP: Exposure of chromatin and not high affinity for dsDNA determines the nephritogenic impact of anti-dsDNA antibodies in (NZBxNZW)F1 mice. Autoimmunity 2009, 42:104-111

82. Borza DB, Neilson EG, Hudson BG: Pathogenesis of Goodpasture syndrome: a molecular perspective. Semin Nephrol 2003, 23: $522-531$

83. Saxena R, Bygren P, Butkowski R, Wieslander J: Entactin: a possible auto-antigen in the pathogenesis of non-Goodpasture anti-GBM nephritis. Kidney Int 1990, 38:263-272

84. LeBlanc BA, Urowitz MB, Gladman OD: Serologically active, clinically quiescent systemic lupus erythematosus: longterm followup. J Rheumatol 1994, 21:174-175

85. Gladman DD, Urowitz MB, Keystone EC: Serologically active clinically quiescent systemic lupus erythematosus: a discordance between clinical and serologic features. Am J Med 1979, 66:210-215

86. van der Vlag J, Berden JH: Lupus nephritis: role of antinucleosome autoantibodies. Semin Nephrol 2011, 31:376-389

87. Berden JH, Licht R, Van Bruggen MC, Tax WJ: Role of nucleosomes for induction and glomerular binding of autoantibodies in lupus nephritis. Curr Opin Nephrol Hypertens 1999, 8:299-306

88. Moroni G, Raffiotta F, Ponticelli C: Remission and withdrawal of therapy in lupus nephritis. J Nephrol 2016, 29:559-565

89. Hahn BH, McMahon MA, Wilkinson A, Wallace WD, Daikh DI, Fitzgerald JD, Karpouzas GA, Merrill JT, Wallace DJ, Yazdany J, Ramsey-Goldman R, Singh K, Khalighi M, Choi SI, Gogia M, Kafaja S, Kamgar M, Lau C, Martin WJ, Parikh S, Peng J, Rastogi A, Chen W, Grossman JM: American College of Rheumatology guidelines for screening, treatment, and management of lupus nephritis. Arthritis Care Res (Hoboken) 2012, 64:797-808

90. Brenowitz M, Senear DF, Shea MA, Ackers GK: Quantitative DNase footprint titration: a method for studying protein-DNA interactions. Methods Enzymol 1986, 130:132-181

91. Hsieh M, Brenowitz M: Quantitative kinetics footprinting of protein-DNA association reactions. Methods Enzymol 1996, 274: 478-492

92. Hedberg A, Fismen S, Fenton KA, Fenton C, Osterud B, Mortensen ES, Rekvig OP: Heparin exerts a dual effect on murine lupus nephritis by enhancing enzymatic chromatin degradation and preventing chromatin binding in glomerular membranes. Arthritis Rheum 2011, 63:1065-1075

93. Pedersen HL, Horvei KD, Thiyagarajan D, Seredkina N, Rekvig OP: Murine and human lupus nephritis: pathogenic mechanisms and theoretical strategies for therapy. Semin Nephrol 2015, 35:427-438

94. Monneaux F, Muller S: Epitope spreading in systemic lupus erythematosus: identification of triggering peptide sequences. Arthritis Rheum 2002, 46:1430-1438

95. Kaliyaperumal A, Michaels MA, Datta SK: Antigen-specific therapy of murine lupus nephritis using nucleosomal peptides: tolerance spreading impairs pathogenic function of autoimmune $\mathrm{T}$ and $\mathrm{B}$ cells. J Immunol 1999, 162:5775-5783

96. Eilat E, Dayan M, Zinger H, Mozes E: The mechanism by which a peptide based on complementarity-determining region-1 of a pathogenic anti-DNA auto-Ab ameliorates experimental systemic lupus erythematosus. Proc Natl Acad Sci U S A 2001, 98:1148-1153

97. Hahn BH, Singh RR, Wong WK, Tsao BP, Bulpitt K, Ebling FM: Treatment with a consensus peptide based on amino acid sequences in autoantibodies prevents $\mathrm{T}$ cell activation by autoantigens and delays disease onset in murine lupus. Arthritis Rheum 2001, 44: 432-441 